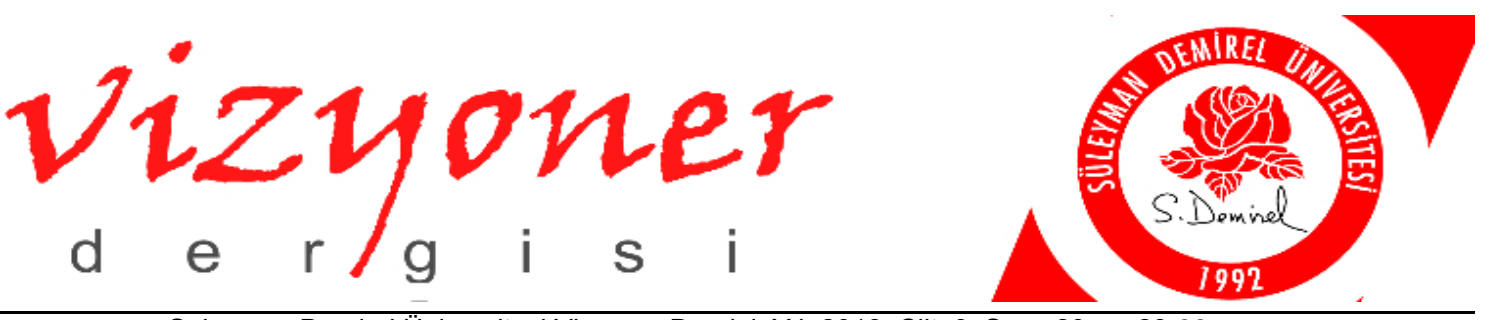

Süleyman Demirel Üniversitesi Vizyoner Dergisi, Yıl: 2018, Cilt: 9, Sayı: 20, ss.28-38. Suleyman Demirel University Visionary Journal, Year: 2018, Volume: 9, Number: 20, pp.28-38.

\title{
REJİ ŞİRKETİ CİBALİ TÜTÜN FABRİKASI İŞÇİ GREVLERİ (1883-1925)
}

\section{THE STRIKES OF WORKERS OF REGIE COMPANY'S CIBALI TOBACCO FACTORY (1883-1925)}

Prof. Dr. Tiğinçe OKTAR ${ }^{1}$

Arş. Gör. Mehmet Mubarek ALAN²

\section{ÖZ}

Ücretli emeğin olduğu her dönemde grevlere rastlamak mümkündür. İşci ve işveren arasındaki ilişkinin dengeli seviyede ilerleyebilmesi için, işçiler grev silahını geçmişten günümüze kullanmıştır. 19. yüzyılda Osmanlı ekonomisinde görülen sanayileşme hareketleri ile birlikte grevlerin de arttı̆̆ını görülmektedir. Özellikle tütün sektöründeki sanayileşme ile birlikte ortaya çıkan tütün işçilerinin grevleri, Osmanlı emek tarihinde önemli bir konumdadır. Tütün tekelini elinde bulunduran Reji Şirketi'nin işçilerine sunmuş olduğu çalışma koşulları, ücretler ve mesai saatlerini içeren ağır düzenlemelerine karşı, işçiler zaman zaman grevlere giderek, daha iyi çalışma şartları için direnmişlerdir. Şirketin, İstanbul'daki fabrikası olan, Cibali Tütün Fabrikası işçilerinin grevleri genellikle tepkisel karakterli olmuş ve grev sebepleri ise sadece ekonomik kaynaklı değil, sosyal sebeplerde olmuştur. Cibali Reji işçisi zihniyetinde, grevler süresince oluşan "işçi sınıfi bilinci" dikkat çekmektedir. Bu bilinç, yapılan grevlerle birlikte gelişmiş ve sosyalizm düşüncesi böylece Osmanlı işçileri arasında yaygınlık kazanmışsa da, söz konusu gelişmeleri devlet izleyerek, önlem almış ve bu düşüncenin İstanbul'da gelişimi yaygınlık kazanmamıştır.

Anahtar Kelimeler: Reji Şirketi, Tütün İnhisarı, Osmanlı Emek Hareketleri, Osmanlı Grevleri.

JEL Sinıflandırma Kodları: N35, N65.

\begin{abstract}
It is possible to encounter strikes in every period of paid employment. In order to balance the worker- employer relations, workers have always used strikes from past to present. Together with the industrialization movements in the $19^{\text {th }}$ century in the Ottoman economy, it is seen that the strikes also increased. The strikes of the workers of tobacco sector that particularly occurred with the industrialization in the sector, have a crucial effect on the history of Ottoman labor. In response to the aggravated working conditions, wages and working hours offered to the workers by the Regie Company that monopolize the tobacco sector, the workers have resisted for better working conditions by going on strikes from time to time. The strikes of the workers of the Cibali Tobacco Factory which is the İstanbul plant of the Company have been reactional and the grounds of the strikes have been not only economic but also social. The "working-class consciousness" of the Cibali Regie workers during the strikes draws attention. This consciousness has improved with the strikes and although the idea of socialism has gained wide currency among Ottoman workers, by watching the developments and by taken precautions the government hindered the idea to disperse in İstanbul.
\end{abstract}

\footnotetext{
Marmara Üniversitesi, İktisat Fakültesi, İktisat Bölümü, toktar@marmara.edu.tr, https://orcid.org/0000-0002-1719-277X

2 Süleyman Demirel Üniversitesi, İktisadi İdari Bilimler Fakültesi, İktisat Bölümü, mehmetalan@sdu.edu.tr, https://orcid.org/0000-00033968-8300
} 
Süleyman Demirel Üniversitesi Vizyoner Dergisi, Yıl: 2018, Cilt: 9, Sayı: 20, ss.28-38.

Suleyman Demirel University Visionary Journal, Year: 2018, Volume: 9, Number: 20, pp.28-38.

Keywords: Regie Company, Tobacco Monopoly, Ottoman Labor Movements, Ottoman Strikes.

JEL Classification Codes: N35, N65.

\section{GİRIŞ}

Grev, işçilerin bir iş kolu veya bir iş yerinde haklarını elde edebilmek için çalışmayı durdurmak ya da işi büyük ölçüde aksatmak olarak tanımlanmaktadır. Osmanlı çalışma hayatında grev, sanayileşme olgusu ile karşımıza çıkmış ve artan sanayileşme hareketleri ile doğru orantılı bir şekilde artış göstermiştir. Ancak sanayileşme döneminin öncesinde de grevlere rastlamak mümkündür; çünkü ücretli çalışmanın olduğu her dönemde grevlere rastlanmıştır. Osmanlı Devleti'nde gelişen yeni sektörler, işçi ihtiyacını da arttırmış ve işçi yığınlarının oluşmasına neden olmuştur. Osmanlı Devleti'ndeki işçiler farklı sektörlerde bulunmaktadır. Bu işçiler sosyal, kültürel ve ekonomik nedenlerle tepkisel nitelikteki işçi hareketlerini oluşturmuşlardır.

Osmanlı Devleti'nde bu işçi hareketleri; grevler, makine kırma-fabrika yakma-kapatma eylemleri, yazılı tepkiler (dilekçe, basın açıklaması vs.), sendikal hareketler, protestolar ve yürüyüşlerdir. İşçilerin en çok başvurduğu ve en etkili sonuçlar aldığı eylem biçimi grevdir.

Osmanlı İmparatorluğu'nda ücretlilerin çalışma koşulları hakkında bildiklerimiz tahminler ve tutulan sınırlı kayıtlardan ibârettir. Ǘcretler, diğer işçi bağlantılı konular gibi az işlenmiş konulardandır. Pamuk'un belirttiğine göre 1880-1889 yılları arasında İstanbul işçisinin aldığı ortalama yevmiye vasıfsız işçiler için 7,9 kuruş, vasıflı işçiler içinse 17,2 kuruş;1890-1899 yılları arasında vasıfsız işçi 8,9 kuruş, vasıflı işçi 19,2 kuruş, 1900-1909 yılları arası vasıfsız işçi 8,3 kuruş, vasıflı işçi 17,9 kuruştur (Pamuk, 2007:166). Elimizde 1883-1914 yılları arasında Cibali reji işçilerinin yevmiyelerine dair resmi kayıtlar bulunmamaktadır. Ancak bu dönemde, Cibali reji işçilerinin yaptıkları grevlerden hareketle, yevmiyeleri ile alakalı sorunlar yaşadıkları sonucunu çıkarabiliriz.

Ücretler konusunda, yine bizlere en doğru bilgiyi verebilecek kaynak 1913-1915 sanayi sayımı istatistikleridir. 1913 yılına ait vasatî yevmiyeler şu şekildedir:

Tablo 1. 1913 Y1lı Ortalama Yevmiyeler

\begin{tabular}{|l|c|}
\hline \multicolumn{1}{|c|}{ Şehir/Bölge } & Kuruş \\
\hline İstanbul & 14.1 \\
\hline İzmir & 12.4 \\
\hline Kömür Havzas1 & 10.1 \\
\hline Beyrut & 9.1 \\
\hline Şam & 8.5 \\
\hline Adana & 7.2 \\
\hline Halep & 7.2 \\
\hline Bursa & 5.3 \\
\hline Humus ve Hama & 5.0 \\
\hline
\end{tabular}

Kaynak: (Eldem,1970:209).

Ortalama yevmiyeler bizlere İstanbul'daki ücretlerin en yüksek düzeyde olduğu bilgisini vermektedir. 1913'te İzmir ve İstanbul Reji Fabrikası işçilerine ödenen tüm ücret 7.755.919 kuruştur, 1915'te; ise ödenen ücret 6.929.662 kuruştur. 1913'te her bir işçiye yılda3.675 ve 1915'te 3.097 kuruş düşmektedir. 1913'te 300 gün hesap ile bir iş̧̧inin ortalama gündeliği 12,3 kuruşa denk gelmektedir(Eldem,1970:209). Bu ücret miktarı tablodan da takip edileceği gibi hem İzmir'in hem de İstanbul'un ortalama günlük ücretlerinin altındadır. Ökçün, ödenen yıllık toplam ücretlere memur maaşlarının da dâhil olduğunu belirtir. Böylece, yevmiyelerin 10 kuruş civarında olduğunu belirtmektedir. Cibali Tütün Fabrikası işçisi ile alakalı elimizde fabrika verileri bulunmamaktadır. İşçi verileri muhtelif kaynaklardan çıkarılmıştır. Bu bağlamda işçilerin ücretleri; 1915 yılı sanayi istatistiklerine göre erkek işçilerin yevmiyesi 10-13 kuruş aralığında değişirken, kadınlar 4-6 kuruş, çocuklar 2-3 kuruş civarında yevmiye almışlardır(Ökçün,1970:71).1924 yılında, kadın işçilerin aldığı ücretin 30-120 kuruş arasında değiştiğini; ancak ekseriyete ödenen ücretin 30-40 kuruş aralığında olduğu görülmektedir (Tütün İşçileri,1340(1924):15). Bu 
Süleyman Demirel Üniversitesi Vizyoner Dergisi, Yıl: 2018, Cilt: 9, Sayı: 20, ss.28-38.

Suleyman Demirel University Visionary Journal, Year: 2018, Volume: 9, Number: 20, pp.28-38.

verilerden hareketle Cibali reji işçisinin, İstanbul işçilerinin ortalama yevmiyesinden daha düşük miktarda yevmiye aldığı görülmektedir.

Çalışma süreleri, yine muhtelif kaynaklardan öğrendiğimiz kadarıyla, 10 ile 15 saat arasında değişmektedir. Makalenin ilgili kısmında görüleceği üzere, grevcilerin taleplerinde genelde mesai saati konusu ve ücretler gündeme getirilmiştir.1913-1915 sanayi sayımı sonuçlarına değişik sektörler de günlük çalışma süreleri yer almasına rağmen tütün imalâtı ile alakalı bilgilere yer verilmemiştir.

Tablo 2. 1913-1915 Sanayi Sayımına Göre Bazı Sektörlerdeki Günlük Çalışma Süreleri

\begin{tabular}{|l|l|}
\hline \multicolumn{1}{|c|}{ Sektörler } & Günlük Çalışma Saatleri \\
\hline Makarna İmalâtı & $10-12$ \\
\hline Şekercilik & $9-11$ \\
\hline Toprak & $10-11$ \\
\hline Dericilik & $11.5-12$ (yazın), 9-9.50(kışın) \\
\hline Ham İpekçilik & 12 \\
\hline Matbaacılık & $9-10$ \\
\hline
\end{tabular}

Kaynak: (Ökçün,1970:75).

Tablodaki verilerden hareketle ortalama günlük çalışma süresinin 10,46 saat olduğu görülmektedir. Bu süre 1913 ile 1915 yıllarına aittir. Ancak 1884 tarihli bir Fransız gazetesinin İngilizce baskısında, Cibali Reji İşçileri'nin az bir öğle tatili ve 15 saatlik bir çalışma süresinin kendilerini güç koşullardan daha çok etkiledikleri ve uzun bir öğle tatili ve çalışma sürelerinin kısaltılmasını talep ettikleri aktarılmaktadır(Oktar,1992:87). Bunlarla birlikte 1920 grevinde işçiler kışın 8 saat, yazın 9,5 saatlik mesai saatinin olmasını talep ederek bu süreçte kendilerine dayatılan mesai saatlerinin 10 saat ve üstünde olduğunu belirtmişlerdir.

\section{OSMANLI DEVLETI'NDE TÜTÜN TEKELİ ILE ALAKALI YAPILAN KURUMSAL DÜZENLEMELER}

\subsection{Reji Şirketi’nin Kuruluşuna Kadar Yapılan Düzenlemeler}

Süreç içerisinde dış borçların ödenmesi için ilk defa, ticari malların üzerinde düzenlemeye gidilmiştir. Bu bağlamda, 1862 yılında tütünün ithalatı yasaklanmış ve gümrük vergileri \% 75 oranında arttırılarak, ülke içerisinde üretilen tütünün önemi arttırılmış ve dolaylı bir tütün tekeli oluşturulmuştur. Bu tekelde tütünün üretimi, imalatı ve satışı kontrol altına alınmıştır.

Oluşturulan bu tekele Mösyö Zarifi ve Hıristaki Efendi'ler talip olmuştur. Bu ilk özel tütün inhisarı olarak adlandırılmaktadır. 12 Mart 1872 yılında ihale edilen ilk özel tütün tekeli, Dersaadet (Suriçi- İstanbul), Bilad-1 Selase (Üsküdar, Galata, Eyüp) ve çevresinde alınıp satılacak tütünün reji kaidesine(tekel)uygun olarak yıllık 400.000 altın karşılığında kendilerine 5 yıl süreyle tütünün alım-satım imtiyazını sağlamıştır. Ama tütüncü esnafının şikâyetleri, basın, ticari rakipler inhisarı elde eden bankerlerin kısa sürede yüksek kâr beklentilerinin yanlış olduğunu ortaya çıkarmıştır. Mösyö Zarifi ve Hıristaki Efendi bu gibi sorunlar nedeniyle, imtiyaz sözleşmesinin feshini istemişlerdir; imtiyaz sözleşmesi 13 Ekim 1872 tarihinde feshedilmiştir (Kazgan, 1999:106).

Tütün tekeli, yaşanan feshin ardından Rüsûmat Emaneti'ne devredilmiştir. Tekel, 1879 yılına kadar devletin yönetiminde, "Bandrol Usulü" ile yönetilmiştir. Uygulama ile beraber devletin kontrolüne tabi olan sigara imalathaneleri sınıflandırılarak, "sarfiyat resmi”"ne tabi tutulmuştur. Satışa çıkacak bütün ürün paketlerinin üzerinde bandrol bulundurulması şartı getirilmiştir. Bu kanunla, uygulanan yeni düzene bandrol usulü ile idare adı verilmiştir. Bu bandrolün olmadığı mallar kaçak sayılarak, denetim daha iyi bir düzeye getirilmiştir. Bandrol sisteminin temel amacı; daha önce tütünle alakalı düzenlemelerle amaçlanan, hazinenin gelirlerini arttırmaktır(Dığıroğlu, 2007:27).

1878 yılında, Osmanlı-Rus Savaşı'ndan mağlup ayrılan Osmanlı Devleti, savaş tazminatını ödemek için Galata Bankerleri'ne 8.725.000 Osmanlı lirası borçlanmıştır. Borcunu ödeyebilmek için devlet bazı gelir kalemlerini Osmanlı Bankası ve Galata Bankerleri’nin hazırladığı teklife istinâden kiralamak durumunda kalmıştır. 22 Kasım 1879 tarihinde yapılan anlaşmaya göre, Rüsûmu Sitte adında bir şirket kurulmuş ve bu şirket tütün, tuz, damga vergisi, müskirattan(içki) alınan ruhsatiye resmi, İstanbul ve çevresindeki balıkçılık resmi ile İstanbul, Edirne ve 
Samsun'un ipek öşrünün haklarını eline almıştır. Rüsûmu Sitte İdaresi, tütüncülük konusunda büyük başarı göstermiştir. Rüsûm-u Sitte İdaresi faaliyete geçtiği tarihten itibaren ilk üç aylık süre içerisinde 465.000 lira gelir göstermiştir ve bu rakamda ilerleyen süreçlerde bu idarenin daha fazla gelir getireceğine işaret etmiştir. İdarenin ilk yıl gösterdiği başarı, Duyun-1 Umumiye'nin kuruluşuna zemin hazırlamış ve Avrupalı alacaklar, bu idareyi Duyun-1 Umumiye'nin bünyesine katmışlardır (Velay,1978:265).

1881 yılında, Osmanlı Devleti'nin borç ödemelerinin yeniden düzenlenmesi gündeme gelmiş ve 20 Aralık 1881(28 Muharrem 1299) tarihinde ilan edilen Muharrem Kararnamesi ile Duyun-u Umumiye kurulmuştur. Bu idare, Osmanlı ekonomisinin başlıca gelir kalemlerini bünyesine katıp, alınmış olan dış borçların ödenmesi için çalışan bir kurum niteliğinde olmuştur (Tabakoğlu, 2009:225). Duyun-u Umumiye İdaresi'nin Rüsûm-u Sitte İdaresi'ne göre çok daha karmaşık bir yapısı olmuştur. Çalışanlarına iyi maaşlar tahsis etmiştir. Dış ülkelerden gelenlere 2.000 sterlin, İstanbul'da ikamet edenlere ise 1.200 sterlin gibi dönemin şartlarına göre oldukça yüksek maaşlar tahsis etmiştir ve her üye Osmanlı hizmetinde çalışan bir memur statüsünde kabul edilmiştir (Oktar, 1992:35).

\subsection{Reji Şirketi(1883-1925)}

Reji Şirketi 1883 yılında, Duyun-u Umumiye’ye bağlı olarak kurulan ve Osmanlı Devleti'nde bandrol usulünün geçerli olduğu bölgelerde, tütünün satın alma, imal edilme ve satılma hakkını elinde bulundurarak, piyasada monopson ve monopol konumda olup, mutlak bir hakimiyet elde etmiştir. Rüsumu Sitte modeli gözönünde bulundurularak bir şartname belirlenmiş ve ona göre çalışma usulü belirlenmiştir.

Şirketin ortakları; Viyana'dan Credit Ansalt, Berlin'den Banker Bleichröder ve Osmanlı Bankası ile ortaklarıdır. Şirket, Osmanlı Devleti'ne yıllık 750.000 Osmanlı lirası ödeme yükümlülüğünde olmuştur ve 30 yıllık imtiyaz hakkını elde etmiştir. Gelir dağılımı; Duyun-u Umumiye, Hükümet-i Seniyye ve Reji Şirketi arasında yapılmıştır. Burada dikkat çeken nokta gelir arttıkça devletin gelirden aldığı payların artması olarak görülürken, şirket ve Duyun- u Umumiye'nin paylarının düşmesidir (Bkz. Tablo 1).

Tablo 3. Reji Şirketi Gelirlerinin Ortaklar Arasındaki Dağılımı

\begin{tabular}{|l|c|c|c|}
\hline $\begin{array}{c}\text { Şirket Geliri } \\
\text { (Osmanlı Lirası) }\end{array}$ & Duyun-u Umumiye Hissesi\% & Hükümet-i Seniye Hissesi\% & Reji Şirketi Hissesi\% \\
\hline $1-500.0000$ & 35 & 30 & 35 \\
\hline $500.000-1.000 .000$ & 34 & 39 & 27 \\
\hline $1.000 .000-1.500 .000$ & 30 & 52 & 18 \\
\hline $1.500 .000-2.000 .000$ & 20 & 70 & 10 \\
\hline $2.000 .000+$ & 15 & 75 & 10 \\
\hline
\end{tabular}

Kaynak: BOA, İ. MMS 3367(1300/1883).

Reji Şirketi, Osmanlı Devleti’nde ve Osmanlı toplumunda büyük bir yer kaplamıştır. Çünkü, şirketin çalışma şartnamesi hem üretici hem de tüketici için ağır koşullar getirmekte ve üretici ile tüketiciyi zor durumda bırakmaktadır. Bu bağlamda tütün kaçakçılığı faaliyetleri artış göstermiş ve şirketin kaçakçılığı önlemek için oluşturduğu silahlı birlikleri olan kolcular, kaçakçılık yapan Osmanlı vatandaşlarına sıkı bir denetim getirmişlerdir (Mutluçağ, 1967:36). Bu sıkı denetimlerin çoğu zaman bir sınırı olmamakla birlikte, kolcu birlikleri ile olan çatışmalarda her iki taraftan ölen insan sayısının 20.000 civarında olduğu belirtilmiştir (Şanda, :87) "Kolculuk" kurumu ilk dönemlerde derme çatma birliklerden kurulmuş; ilerleyen süreçlerde, atlı birlikler oluşturulmuş, silahlı birlikler bulundurulmuş ve hatta kadın kolcu birlikleri oluşturulmuştur. Bunlarla birlikte Reji İdaresi'nin deniz örgütlenmesine de rastlamak mümkündür. 1894 yılında, rejinin 6 adet gemisi ve 23 adet sandalı bulunmaktadır (Erkson, 1954:97).

Devletin bu durum karşısında hukuken yapabileceği bir müdahale bulunmamaktadır; çünkü şirketle yapılan anlaşma gereği, şirketin eylemleri hukuk sınırları içerisinde yapılmıştır. Reji Şirketi'nin 30 yıllık imtiyazının sonunda, 1912 yılında Tütün Kanunu Tasarısı hazırlanmış ve devlet tütün tekelini kendisi işletmeye karar vermiştir. Ancak Trablusgarp ve Balkan Savaşları'nın getirdiği ekonomik yük neticesinde Reji Şirketi'nden 1.500.000 Osmanlı lirası borç alınmış ve şirkete 15 yıllık imtiyaz süresi tanınmıştır (Cemal Paşa, 2012:91).

Milli mücadele döneminde Mustafa Kemal, milli ekonominin olması gerektiğini belirtip buna göre hareket etmiştir. Bu bağlamda, 1920 yılında Balıkesir Reji İdaresi’ndeki paranın kendisinden veya şehir muhasebecisinden 
Süleyman Demirel Üniversitesi Vizyoner Dergisi, Yıl: 2018, Cilt: 9, Sayı: 20, ss.28-38.

Suleyman Demirel University Visionary Journal, Year: 2018, Volume: 9, Number: 20, pp.28-38.

habersiz kullanılmamasını belirtmiş ve bu parayı Milli Mücadele için kullanmıştır. 1925 yılında Reji Şirketi 4.000.000 Türk lirasına satın alınmış ve böylece Reji Şirketi devletleştirilmiştir.

\section{CIBALİ REJI FABRIKKASI İŞÇiLERINIIN GREVLERI}

Reji işçilerinin grevlerini çalışmadan önce, bilinmesi gereken Osmanlı Devleti'nin emek hareketlerine karşı yapmış olduğu düzenlemelerdir. Çünkü bunlarla birlikte devletin grevlere müdahale hakkı meşruiyet kazanmakta ve dönemin siyasi ve sosyal ortamının grevlere olan etkisi daha iyi anlaşılacaktır.

\subsection{Osmanlı Devleti’nde Emek Hareketleri ile Alakalı Yapılan Düzenlemeler}

Osmanlı Devleti'nde ücretli emeğin olduğu her dönemde tepkisel hareketlenmeler görülmüştür; ancak lonca sisteminde kendi denetimini yapan bir mekanizma olduğu için devletin müdahale etmek için ayrıca düzenleme yapmasına ihtiyaç olmamıştır. Ancak lonca sistemi işleyemez duruma gelince, 19. yüzyılda özgür iş gücü tepkisel nitelikteki eylemlerini başlatmıştır ve buna istinâden ilk düzenlemeler yapılmıştır.

1845 yılında çıkarılan Polis Nizamnamesi(BOA, 1331/1913)'nin 12. maddesi doğrudan emek hareketleri ile ilgiliydi. Bu madde sadece İstanbul sınırları içinde geçerli olacaktı ve işçilerin cemiyet kurmaları, kamu düzenini etkileyebilecek eylemlerde bulunmaları ve grev yapmaları yasaklanıyordu. Grev yapılması halinde müdahale edilebilmesinin meşru zeminini nizamnamenin bu maddesi sağlamıştır. Sözkonusu madde de ayrıca bu eylemlerin toplumda fitne ve fesada sebep olduğu belirtilmektedir.

1908 yılında II. Meşrutiyet'in ilan edilmesi ve II. Abdülhamid'in hal'edilmesi ile birlikte, kurulan yeni meclisin iktidar partisi-İttihat ve Terakki Partisi- topluma sağlayacağını taahhüt ettiği "hürriyet, musâvat, uhuvvet,adalet" ortamından hareketle işçilere yeni haklar tanınmasına karar vermiştir. Böylece bu durum işçiler arasında bir grev dalgasının yayılmasına sebep olmuştur; ancak bu durum ekonomiyi kötü etkileyince, 1908 yılında Terk-i Eşgal ya da Ta'til-i Eşgal Kanunu(Düstur, 1325/1909)'nu hazırlayarak grev yapılabilmesini belli şartlara bağlamıştır. Yasaya adını veren "terk-i eşgal” kavramı grev anlamına gelmektedir. Kanunun 6., 8. ve 10. maddeleri kamuya yönelik hizmette bulunan işçilerin grev yapamayacağını, grevi başlatan konumdaki sorumluluların para ve hapis cezalarına çarptırılacaklarını, kanunun yürürlüğe girdiği tarihten itibaren sendikaların hukuken yok sayılacakları ve yine kamuya yönelik hizmette bulunan işçilerin kesinlikle sendika kuramayacakları belirtilmiştir.

Cemiyetler Kanunu (Düstur, 1325/1909)1909 yılında çıkarılmıştır ve sendika kurmanın esaslarını 19 maddede belirtmiştir. Bu kanunla cemiyet kurma özgürlüğü tanınmıştır, kurulan cemiyetin Hariciye Vekâleti'ne bildirilme zorunluluğu bulunmaktadır. Kanunla birlikte cemiyetlerin hangi özelliklere istinaden kurulamayacakları belirtilmiştir. Buna göre; genel ahlak kurallarına aykırı cemiyet kurulamayacağı, ırk ve cinsiyet temelli cemiyetlerin kurulamayacağı, kurulan cemiyetin bildirilmesi, cemiyet merkezinde ateşli-yaralayıcı silahların bulundurulamayacağı belirtilmiştir.

\subsection{Cibali Tütün Fabrikası}

Reji Şirketi'nin Osmanlı Devleti'nin çeşitli yerlerinde fabrikaları olmuştur; bunlar İstanbul, İzmir, Samsun, Adana, Şam ve Halep fabrikalarıdır. İstanbul'daki fabrika Cibali Tütün Fabrikası'dır ve kayıtlara göre en fazla tütün ürününün imâl edildiği fabrikadır (Quataert, 1987:18). Cibali Tütün Fabrikası'nın üretim yaptığı binasında, günümüzde Kadir Has Üniversitesi bulunmaktadır.

$\mathrm{Bu}$ fabrikada üretim beş işçi grubunun çalışmasıyla gerçekleşir. Bunlar;tütüncüler, kesimciler, sigaracılar, paketçiler ve denetçilerdir. Tütüncüler, çeşitli yörelerden gelen tütün yapraklarını belli oranlarda karıştırıp; bir harman elde eder, bu işlem sigaranın kalitesi için çok önemlidir; bu yüzden bu işte ustalaşmış erkekler bu işçi grubunu oluşturmaktadır. Kesimci grubu, yine erkeklerden oluşmuştur, bunlar harman olarak gelen tütünü havan(otomatik bıçaklı makine) ile ya da manuel bıçaklı makinelerle kıymışlardır. Sigaracı ve paketçi grubu kadınlardan oluşmaktadır. Kadınların elleri, erkeklerinkine göre daha ince yapılı olduğu için sigara sarma işini daha ustalıkla yapmaktadırlar, bu yüzden bu iş için kadınlar seçilmiştir. Paketçi grubunun yaptığı da, sigara olarak sarılmayan tütünün "paket tütün" şeklinde satımı için, küçük karton paketlere doldurulmasından ibarettir. Ancak bu iş göründüğü kadar kolay değildir; çünkü işçiler ellerini tartı gibi kullanarak her pakete aynı gramajda tütün koymak mecburiyetindedir. En son yapılan paketlerin tartımı işleminde, istenen gramaj çıkmaz ise, paketlemenin tekrardan yapıldığı görülmüştür. Denetçi grubu işçileri, genelde kadınların çalıştığ 1 salonda bulunur ve çıkan işlerin denetimini sağlardı, bunlar erkek işçilerden seçilirdi (Balsoy, 2012:62-63). Tütüncü, sigaracı ve paketçi grubunun kendilerine yardım eden çırakları bulunmaktadır. 
Süleyman Demirel Üniversitesi Vizyoner Dergisi, Yıl: 2018, Cilt: 9, Sayı: 20, ss.28-38.

Suleyman Demirel University Visionary Journal, Year: 2018, Volume: 9, Number: 20, pp.28-38.

\subsection{Cibali Reji İşçilerinin Grevleri}

Cibali Reji işçilerinin 1883 ve 1925 yılları arasında tespit edebildiğimiz 7 tane grevleri olmuştur. Bu grevler karakteristik anlamda birbirlerinden farklı sebeplerle ortaya çıkmışlardır. Greve katılım konusunda işçilerin özellikleri belirleyici olarak görülmüştür. Bu özellikler; işçilerin yaşları, cinsiyetleri, dini ve etnik kimlikleridir.

Bu grevlerde, ilerleyen süreç içerisinde oluşan “işçi sınıfı bilinci”nin oluştuğu görülmüştür. Grevlere katılım konusunda arşiv belgelerinde kesin bilgiler bulunmamaktadır. Ancak, bazı çıkarımlar yapılarak 2 greve tüm işçilerin katılabildiği söylenebilmektedir. Grevlerin süreleri ile alakalı da kesin sayılar bulunmamaktadır. Ancak bu grev sürelerinin 7 ile 30 gün arasında değiştiğini söylemek mümkündür; çünkü yönetim, grevlerinde devam etmekte ısrarcı olan işçilerin, sözleşmelerini feshetmek ile tehdit ederek, grevleri sonlandırmaktadır.

\subsubsection{3-Nisan Grevi}

Cibali Tütün Fabrikası'nda tespit edilen ilk grev 1893-Nisan Grevi(BOA,1310/1893) olmuştur. Bu grevin ortaya çıkma sebebi, çalışma koşullarındaki zorluklardan kaynaklanmıştır. Buna göre, 52 işçi 27 Nisan 1893 'te fabrikada bulunan havan makinesinin genişliği nedeniyle tütünleri elle bastırmakta zorlandıklarını belirtmiş ve makine kaynaklı çalışma koşullarının zorluğu sebebiyle greve başlamıştır. Fabrika yönetimi bu grevin daha fazla büyümemesi ve işlerin aksamaması için, işçilerin eski usul çalışabileceklerinin iznini vermiştir. Ancak işçiler grevi sonlandırmamış ve ücret azlığından şikâyet edip grevi devam ettirme kararı almışlardır.

Bunun üzerine fabrika yönetimi, devlet makamları ile iletişime geçmiş ve fabrika önünde toplanan işçi grubuna müdahale edilmesini istemiştir. Fabrika yönetimi ayrıca grevi bırakıp, işinin başına dönenlerin işlerine herhangi bir şekilde dokunulmayacağını; ancak greve devam hususunda ısrar edenlerin işlerine son verilip, bir daha işe alınmayacaklarını belirtmiştir. Grev böylece sonlandırılmış ve grevi organize etmekle suçlanan beş kişi de işten çıkarılmıştır.

Makine kırma(luddisme) eyleminin, bu grev sırasında uygulandığı görülmektedir. Ricardo’ya göre ücretlerdeki düşme ve insanların işlerini kaybedebilme riski, otomasyona karşı verilen tepkilerin ana sebebi konumundadır (Ricardo, 2008:348-349). Ancak Osmanlı Devleti'ndeki makine kırma eylemleri, genel olarak Osmanl toplumunun ülkeye yeni giren batı teknolojisine karşı, geleneği savunan eylemleri olarak tanımlanmıştır. Bu bağlamda 1861 yılında mezarlık üzerine kurulduğu iddia edilen Bursa'daki fabrika binasının ateşe verilmesi bu tezi kanıtlar niteliktedir (Karakışla, 1998:29). Bu grevin sebebinde görüldüğü gibi, geleneksel yöntemlerle tütün kıyan işçinin makineyi kullanmaktan imtinâ ettiği ve eski usul çalışmaya dönmek için grev yaptığı görülmektedir.

\subsubsection{4-Kasım Grevi}

İlk grevden yaklaşık 11 yıl sonra, 30 Kasım 1904 yılında Cibali işçilerinin ikinci grevleri olmuştur. Bu grevden haberdâr olmamızı sağlayan belgede(BOA Y.A.HUS,1322/1904), "o yolun bir hareket-i sûi misal teşkil ederek pek muzır neticeler tevlid edebileceğine” ifadeleri kullanılarak, bu gibi eylemlerin başka işçi grupları içinde örneklik teşkil edebileceği ve başkentte birçok sıkıntılı meseleye sebep olabileceği belirtilmiştir. Belgede bahsedilen bir başka konuda, bu tür eylemlerin destekleyicisi konumunda olabilecek bu olayın, Selanik tarafındaki reji işçilerinin kışkırtmalarıyla olduğudur ve bununla birlikte, böyle olayların yaşanmaması için tedbirlerin alınması gerektiği belirtilmiştir.

Bahsedilen tedbirlerden kasıt Cibali civarındaki karakola bir yüzbaşı kumandasında bir miktar nizamiye askerinin gönderilmesi ve ayrıca Zabıta Nezareti'nce yirmi kadar zabıtanın bunlarla birlikte görev yapmasıdır. Belge, ayrıca ameleyi kışkırtanların eşkâli hakkında da bilgiler vermektedir. Buna göre; üç-beş Rum ve İtalyan ve Alman'ın "eşnümacı ile teşrik-i fikir vasıl ederek diğer ameleyi bir müddetten beri umumen ta'til-i eşgâle teşvik etmekte oldukları" ifadelerinden anlaşıldığ kadarıyla, grevin sorumlulularına işaret edilmiştir (BOA,1322/1904).

Aynı grevle alâkalı tutulan başka bir belgede (BOA DH. MKT., 1322/1904), grev kışkırtıcılarının belirlendiği ve gerekli cezaların verildiği belirtilmiştir. Buna göre; Cibali Tütün Fabrikası'nda bir İtalyan vatandaşı ve 11 Yahudi ve biri Ermeni olmak üzere, 13 kişinin grevi başlatanlar olduğu tespit edilmiştir. İşçileri greve teşvik eden İtalyan vatandaşı Sigaracı Nesim'in memleketine teslim edilmek üzere, İtalyan Sefareti'ne teslim edildiği, Vasıl Yani ve Karamanlı Vangel Sarandi'nin; ise Kayseri’ye sürgün edildikleri belirtilmiştir.

$\mathrm{Bu}$ grevde, arşiv belgesinde belirtilen "hareket-i sûi misal" ifadelerinden kastedilenin "sosyalizm" olması gerekmektedir. Çünkü Selanik işçilerinin sosyalist düşüncelerle tanıştığı bilinmektedir. Quataert, Selanik’te sosyalist hareketin tohumunun Yahudi tütün işçileri tarafından atıldığını söylemiştir, tütün işçilerinin kurduğu sendikanın, sınıf esasına dayalı işçi örgütlerinden olduğunu belirtmiş ve bu bağlamda sınıf esasına dayalı ilk 
Süleyman Demirel Üniversitesi Vizyoner Dergisi, Yıl: 2018, Cilt: 9, Sayı: 20, ss.28-38.

Suleyman Demirel University Visionary Journal, Year: 2018, Volume: 9, Number: 20, pp.28-38.

sendikalardan olduğunu söylemiştir; ancak Selanikli tütün işçilerinin sendikası 1909 kurulmuştur ve burada 1904 yılındaki bir grevden bahsedilmiştir (Quataert, 1998:120).

Osmanlı Devleti, başkent olan İstanbul'da herhangi bir karışıklık olmaması için büyük önlemler almış ve bu düşüncelerin(sosyalizm) yayılmasını engellemiştir. 1904 Kasım Grevi'nin, Selanikli işçilerden etkilenerek yapıldığına dair kanıt ise, grev taleplerinin aynı dönemde Selanik’te devam eden grevin talepleri ile büyük ölçüde benzer olmasidır.

\subsubsection{6-Mart Grevi}

Arşiv belgelerinde bu grevle alakalı tarih 5 Safer 1324(31.03.1906) olarak geçmektedir. Belgeden anlaşıldığ kadarıyla, Paskalya Bayramı münasebetiyle işlemeyen haftalıklarına mahsuben bir miktar para verilmesini ve böylece grev yapanların, grevlerini bitirmelerini belirtmiştir, bu ifadelerden grev yapanların dini kimliklerinin Hristiyan olduğunu görmekteyiz (BOA, 1324/1906).

$\mathrm{Bu}$ grevle alâkalı bir gün sonra tutulmuş olan belgede, grevin Rum ve Musevi işçiler tarafından yapıldığı belirtilmektedir. $\mathrm{Bu}$ belgeye göre, greve katılanların 2.000 kişi civarında olduğu sanılmaktadır. Ancak aynı belgede, gelen ihbârın yanıltıcı olduğu ve greve katılanların kadın ve erkeklerden oluşan 200 kişilik bir grup olduğu belirtilmiştir. Greve fabrikanın tütün imalatından sorumlu, harmanları hazırlayan usta işçilerinden kimse katılmamıştır; bunların büyük bir kısmı Müslüman işçilerdir(BOA,1324/1906).

Yıldırım, greve devam eden Rum ve Musevi işçilerin teşvik ve yönlendirmesi ile paket ve sigara işçilerinden, yaşları 10 ile 12 arasında değişen 500 civarında kız çocuğu işçininde greve katıldığını belirtir (Yıldırım,2011:314). Grev haftalık ücretlerin arttırılması talebi ile devam etmiştir ve Hristiyan işçiler ayrıca, ellerinden alınan Paskalya Bayramı'ndaki ücretli izin haklarını tekrar istemekteydiler. Bunlarla birlikte 8 Nisan 1906 tarihli bir başka belgede fabrika yönetiminin sigara imalatı bölümüne bir yıldan beri yeni makineler alma ve makine sayısını arttırma gibi düşünceler içerisinde olduğu belirtilmiştir(BOA,1324/1906). Makine sayısının artması sonucunda, fabrikanın doğal olarak işçi mevcudunda azalmalara gideceği ve grevin nedenlerinden birininde bu olduğu belirtilmiştir.

Grevin sebeplerini incelediğimizde karşımıza 2 etken çıkmaktadır; bunlar dini etken ve otomasyon etkenidir.Dini etkenden ötürü grev katılımcılarının Müslüman olmayan unsurlar olduğu görülmektedir ve Paskalya Bayramı'nda izin yapan işçilerin haftalıklarının ödenmesinin bir hak olduğu belirtilmiştir. Otomasyon etkeni, makineleşmedir; arşiv belgesi, makinelerden ötürü işlerini kaybetme korkusu yaşayan işçilerin bu grevi yapmalarında önemli bir unsur olduğunu belirtmiştir.

Burada göze çarpan bir başka olayda, 1904 grevinde görmüş olduğumuz gibi “işçi sınıfı bilinci”nin geliştiğini gözlemlememizdir. Çünkü 1904 yılındaki grevde, devlet makamları bu grev düşüncesinin Selanikli Sosyalist işçiler tarafından İstanbul işçilerine öğretildiğini belirtmiş ve 1906 grevinde de gördüğümüz gibi fabrika işçilerinin bir unsuru kitlesel bir şekilde grev yapmıştır, burada görüldüğü gibi, Rum ve Yahudi işçiler grevi başlatmış devamında çocuk işçilerde bu greve katılmışlardır.

\subsubsection{8-Ăgustos Grevi}

1908 yılında meşrutiyetin tekrar ilan edilmesi ile birlikte, bir özgürlük ortamı oluşmuş ve işçiler tekrardan hak taleplerinde bulunabilmişlerdir. Ancak işçilerin hak taleplerinde bulunabilmesini sağlayan bu ortam, çokça istismara da yol açmıştır. Mesela; kahveciler, gazinocular vs. eğlence mekanları; geceleri yasal süreleri dolduğu halde güvenlik güçlerinin uyarılarına aldırmayıp, hürriyet var, diyerek mekanlarını kapatmamışlardır. Aynı şekilde mükellefi oldukları vergi veya para cezalarını da aynı gerekçeye dayanarak ödememişlerdir. Tütün alım-satımına yönelik her türlü yetki Reji Şirketi'nin elinde olmasına rağmen; meşrutiyet sonrası, halka açık yerlerde, tütün satış1 açıktan yapılmıştır. Mevzuatın kendilerine okunması ve satış yapamayacakları tebliğ edilmesine rağmen, insanlar tekrardan, hürriyet var diyerek görevlileri geri çevirmişlerdir(BOA,1324/1908).

Bu ortamdan ötürü 1908 yılında Ta’til-i Eşgal Kanunu ilân edilerek, kamu yararına üretim yapan fabrikaların işçilerinin grev yapamayacakları kararı alınmış ve 1909 yılında yine kamu yararına üretim yapan fabrikaların işçilerinin cemiyetleşemeyeceği; yani sendika kuramayacaklarını belirten Cemiyetler Kanunu ilân edilmiştir. Böylece grevlere müdahale, yasal bir zemine oturtulmuştur.

Ağustos ayının başlarında Cibali Tütün Fabrikası işçileri II. Meşrutiyet'in ilk grevini gerçekleştirmişlerdir. Reji işçileri \%100 ücret zammı talep etmişlerdir (Tanin,1324/1908). Ancak Reji Şirketi II. Meşrutiyet'in ilanından iki ay önce işçilerin ücretlerine $\% 30$ zam yapıldığını, işçilerin meşrutiyet ortamını istismar ettiklerini ve pragmatist oldukları gerekçeleri ile bu talebi reddetmiştir (Servet-i Fünun,1324/1908). Ancak 12 Ağustos 1908 tarihli bir 
başka belge, işçilerin grevlerinin ciddiyet kazandığını, işçilerin fabrika binalarına zarar verebileceklerini ve bunlardan ötürü zabıtanın tedbir alması gerektiği belirtmiştir(BOA,1324/1908).

İşçilerin \%100 zam talebine, reji yönetimi \%50 oranında bir zam önermiş ve bu konuda anlaşmak istemiştir; ancak işçiler taleplerinde ısrarcı olunca, Reji yönetimi taleplerini kabul etmemiş ve fabrikayı kapatmıştır. Fabrikanın kapalı kaldığı sürece ücret alamayacak olan işçiler, yönetimin zam teklifini kabul etmek zorunda kalmış ve grevi 14 Ağustos’ta sonlandırmıştır (Toprak,1977:282).

Bu greve, bütün reji işçileri katılmıştır. Burada greve katılımın, fabrika işçi mevcudunun tamamının katılmasını sağlayan faktör, ilan edilen II. Meşrutiyet'in yarattığı özgürlük ortamıdır. Çünkü bir önceki grevde görüldüğü kadarıyla sadece Rum ve Yahudi işçilerin greve iştirak ettiği ve bir işçi sınıfı bilincinin hâla tam anlamıyla oluşmadığı sonucu çıkmaktadır. Ancak 1908 grevinde görüldüğü kadarıyla, hürriyet ortamının bir işçi sınıfı bilinci oluşturabildiği ve din ya da ırk ayrımı olmaksızın greve katılım sağlandığı görülmektedir.

Burada grevin sebebi zam talebi olarak gösterilmiştir. Ancak, bu talep sebep konumunda değerlendirilmemelidir; çünkü hemen hemen bütün grevler mesai saatlerinin düşürülmesi, ücretlerin arttırılması vs. gibi talepleri içeren bir talepler listesini barındırmaktadır. Burada işçileri harekete geçiren ve grev yapmalarına sebep olan kuvvet, özgürlük ortamından faydalanarak isteklerini dile getirmeleridir. Yani talep edilenler grevlerin değişmezleri iken, sebepler dönemin sosyal koşullarıdır.

\subsubsection{1-Nisan Grevi}

Arşiv belgesinden anladığımız kadarıyla 1911 yılının mart ayında Cibali Tütün Fabrikası işçilerinin grevleri olmuştur. Sülker, bu grevin başlangıç tarihini 2 Nisan 1911 olarak belirtir. İşçiler bu grevden önce basına da haber vermiş ve halkı da bu grev konusunda bilgilendirmiş ve halktan destek istemişlerdir (Sülker, 1976:18).

23 işçinin mesaiye geç başladıkları sebebiyle ücret kesintisi ile cezalandırılması işçileri bu grevi yapmaya iten etken olmuştur. Bu grevin özelliği, Cibali Tütün Fabrikası işçilerinin tümünün greve katılmış olmasıdır (Sa'y ve Amel,1327/1911). Grev başlangıcında, greve katılmak istemeyen işçiler olmuştur; ancak öteki işçilerin fiziksel ve psikolojik baskıları işçilerin greve katılmasını zorunlu kılmıştır. Bu konu ile alakalı olarak, greve katılmayan iki kişiye İtalyan asıllı Fransuva adlı bir işçi tokat atmış, bu tokattan ötürü grev ortamında herhangi bir kavganın yaşanmaması için zabıta önlem almıştır(BOA.1329/1911).

Bu greve kaç kişinin katıldığı hakkında kesin bilgiler bulunmamaktadır; ancak Velikov bu sayının 3.000 civarında olduğunu belirtmektedir (Velikov, 1964:46). İşçilerin bu grevle alakalı, ücretlerden başka talepleri de olmuştur. Bunlar; 9 saatlik çalışma süresinin kısaltılması, sağlık koşullarının iyileştirilmesi, 14 yaşından küçüklerin çalıştırılmaması, yardım sandığı gibi sosyal hakları talep etmişlerdir(Balsoy,2009:65).

Grevcilerin taleplerine karşı şirket yönetimi uzlaşmacı bir tavır takınmamış ve grevi bırakıp, işine başlamayanların istifa etmiş sayılıp, tekrardan işe alınmayacakları belirtilerek, işçileri işleri ile tehdit etmişlerdir. İşçiler bu tehditten sonra grevi bırakmışlardır(BOA,1329/1911). Ancak bu grevin etkileri 1912 yılına kadar devam etmiştir. 09.04.1911 ile 12.08.1912 yılları arasında seri şeklinde tutulmuş belgelerde, grevin devam edebilecek etkilerine karşı alınabilecek tedbirler belirtilmiştir. Bu tedbirlerle birlikte, Cibali Karakolu'ndaki zabıta kuvvetlerinin fabrikanın bütün işçileri karşısında yetersiz kaldığı, Cibali civarındaki jandarma ve polisten yardım alındığı ve bununda yeterli olmadığı görülüp Unkapanı Polis Merkezi’nden takviye alındığı anlaşılmaktadır (BOA, 1330/1912).

1911 Nisan Grevi’nin öncesi ve sonrasında yaşananlar Cibali Tütün Fabrikası işçilerinin artık belli bir işçi bilinci düzeyine eriştiğini göstermiştir. Burada özellikle, işten çıkarılan 23 işçi için tüm işçilerin greve katılmaya zorlanması bir işçi sınıfının oluştuğunun ve birlikte hareket ederek sonuç alabilmenin imkânını göstermesi açısından önemlidir. Ancak ekonomik anlamda zor durumda bulunan Cibali Tütün işçisi ve 1908 Terk-i Eşgâl Kanunu'nun getirdiği müdahale hakkı neticesinde ve bunlarla birlikte şirket yönetiminin tehditkâr tavrı sebebiyle grev başarılı olamadan sonlandırılmıştır.

\subsubsection{9-Şubat Grevi}

1911 yılındaki grevden sonra uzun bir süre grev yaşanmamıştır. Özellikle 1914 yılında başlayan 1. Dünya Savaşı'nın başlaması ile birlikte işçi hareketleri için bir sessizlik süreci başlamıştır. Çalışabilir nüfusun önemli bir kısmı silahaltına alınmıştır. Bu dönemde işçiler 1919 yılına kadar grev yapmamışlardır. 1919 yılı için tespit edilen ilk grev Cibali reji işçilerinin grevidir. Yıldırım bu grevin, ücretlere zam yapılması talebiyle başlatıldığını belirtmektedir(Yıldırım,2011:428). Araştırmamızda bu greve dair arşiv kaydına rastlanmamıştır. 
Süleyman Demirel Üniversitesi Vizyoner Dergisi, Yıl: 2018, Cilt: 9, Sayı: 20, ss.28-38.

Suleyman Demirel University Visionary Journal, Year: 2018, Volume: 9, Number: 20, pp.28-38.

\subsubsection{0-Haziran Grevi}

1920 yılı mayıs ayı sonlarında Cibali reji işçileri idareden birtakım taleplerde bulunmuşlardır, idare bu talepleri kabul etmeyince greve gitme kararı almışlardır (İkdam Gazetesi,1336/1920). Bu karar 1 Haziran'a denk gelmiştir. İşçiler fabrika yönetiminin kendilerini yazın 9,5 saat, kışın 8 saat çalıştırması gerektiğini belirtirken, yönetimin kendilerini her gün fazla mesaiye kalmaya zorladığını belirtmişlerdir. Fazla mesai ücretine saat başı \%100 zam yapılmasını talep etmişlerdir, ancak yönetim kendilerine \%50 civarında bir zam teklifini götürmüştür.

Bu talebi kabul etmeyip, greve gidenlerin fabrika ile ilişkileri kesilmiş ve işlerine son verilmiştir. İşine son verilen işçilerin 1400 kişi olduğu belirtilmiş ve işçilerin Dahiliye Nezareti ve Reji komiserini olaya dahil edip, bu sorunun çözülmesi talebinde bulunmuşlardır (İkdam Gazetesi,1336/1920).Reji Şirketi, Tramvay ve Tünel Şirketleri’nin taktiklerini kullanarak ücretlere yapacağı zam için, ürünlerinin satış fiyatlarına \%40 oranında bir artış yapmayı planlamıştır. Bu olay üzerine Cibali Tütün Fabrikası işçilerinden birinin ifadesi şu şekildedir: "Şirket bizi fazla çalıştırmak suretiyle depolarını doldurmuş olduğundan bize yol vermekte tereddüt etmedi ve nihayet çoluk çocuğumuzla sokak ortasında kaldık. Bu acınacak hale acil bir çare bulunacağını ümit ederiz. ”Reji yönetimi ve işçiler arasındaki ihtilaf bir müddet sonra Dahiliye Nezareti, Maliye Nezareti ve Reji Şirketi arasındaki müzakerelerle çözülmüş ve işçiler işlerine geri dönmüşlerdir.

Bu grevde görüldüğü gibi, greve katılanların 1400 işçi olduğu belirtilmiştir. Bu elimizde kesin kayıtlar olmamasına rağmen, fabrika işçi mevcudunun tamamı olabilecek sayıdadır; çünkü 1883-1925 arası dönemde fabrikanın işçi mevcudu 1000-1500 işçi arasında değişmektedir. Yine bu grevde de görüldüğü gibi grev talepleri benzerdir ve sebep sosyo-ekonomiktir. Bu grevin sebebi konumundaki olay angaryadır. İşçilerin bu haksızlığa karşı koymak için birlikte hareket ettikleri görülmektedir. Ancak zor durumda bulunan devlet otoritesinin açığından faydalanan Reji Şirketi monopollük haklarını kullanarak, işçilere yapacağı zammı fiyatlarına fazlasıyla yansıtacağını belirtmiştir.

\section{SONUÇ}

Son dönem Osmanlı ekonomisi incelendiği vakit, geleneğin devam ettirilmeye çalışıldığı görülmektedir. Ancak; gelenek yeni paradigmalar oluşturularak devam ettirilemediği için, devlet kurum ve işleyişinde yenilenme hareketlerini görmekteyiz. Bunun ilk örneği 18. yy. 1slahatları ile başlarken, 19. yy.'da da daha kitlesel bir dönüşüm yaşanmış ve Tanzimat Fermanı (1839) ilan edilerek, devlet kurumlarında modernite süreci başlatılmıştır.

Ancak bu modernleşme süreci ekonomideki istenen değişimi sağlayamamış ve Osmanlı Devleti ilk dış borcunu 1854 'te alarak, ekonomide yeni bir süreci başlatmış, ilerleyen süreçte görüldüğü gibi 1875 moratoryumu ilan edilerek ekonomideki egemenlik hakları İngiltere'ye devredilmiştir. Yapılan planlamalar neticesinde, borçların ödenmesi için tütün sektöründe tekel oluşumuna gidilmiş ve bunun kontrolü, yine borçların ödenmesi için ekonomi yönetimini sağlayan Duyun-u Umumiye’ye bağlı olarak kurulan Reji Şirketi’ne verilmiştir.

Reji Şirketi tütün sektörü üzerinde mutlak bir hakimiyet kurmuş ve üretim ile tüketimin her aşamasında gelir elde etmiştir. Burada Reji Şirketi’nin yapmaya çalıştığı tütün sektörünü geliştirmekten çok, tütün üzerinden şirketin nasıl daha fazla gelir elde edebilmesidir. Bunun en göze çarpan kanıtları, Reji Şirketi'nin tütün alım ve satım fiyatları arasındaki büyük farklar, elde ettiği gelirler ve kolcu birliklerinin devreye sokulmasıdır. 1885-1886 yılları arasında tütün alım fiyatı kilogram başına 7,6 kuruş iken, satış fiyatı 26,10 kuruş; 1904-1905 yılları arasında alım fiyatı 6,5'e düşmüş ve satış fiyatı 28,1 kuruşa çıkmıştır,1910-1911 yılları arasında alım fiyatı 7,8 kuruş iken, satış fiyatı 34,07 kuruştur. Verilen üç yıl aralığında alım fiyatlarında fazla değişiklik olmaz iken, satış fiyatlarındaki değişim göze çarpmaktadır; bunlarla birlikte aynı yıllardaki gelire baktığımızda ise, şirketin geliri 1885-1886 yılları arasında 650.000 Osmanlı liras1, 1904-1905 yıllar1 aras1 gelir 811.623 Osmanlı liras1, 1910-1911 y1lları aras1 gelir 1.049.443 Osmanlı lirasıdır. Şirket bu alım-satım fiyatlarını hükümet komiserinin de dahil olduğu bir komisyonla belirlemektedir; ancak tütün imalatçısı ve üreticilerinin muzdarip olduğu bir başka konu da reji komiserinin görevini yapmadığı üzerinedir. Dolayısıyla burada rejinin, çalışma şartnamesindeki şartlara uyarak fiyatları belirlediği görülmekte, ancak kaçakçılık vakalarındaki artışa bakıldığında da ortada adaletsiz bir durumun olduğu ve rejinin tütüncülük sektörünü geliştirmekten çok, gelir elde etme kaygısının öne çıktığı görülecektir.

$\mathrm{Bu}$ verilerden hareketle yıllar içerisinde alım fiyatlarındaki değişimin az olduğunu, ancak satış fiyatlarındaki değişimin artan bir trend takip ettiğini ve bunlarla üreticinin kazancının düşük seviyelerde kalırken, aynı zamanda üretici kısım olan fabrika işçilerinin de bu makalede anlattığımız gibi yetersiz yevmiyelerinden ötürü grev yaptıkları bilinmektedir. Yine bunlarla birlikte gelirin artan bir trend takip ettiği ve şirketin herhangi bir şekilde 
kaçakçılığa müsaade etmeyerek kolcu birliklerini oluşturduğu bilinmektedir. Kolcu birliklerinin şirkete bir maliyeti vardır; ancak ortaya çıkan rakamlar, tütün üreticisi ve imalatçısının az kazandığını ve sadece şirketin kâr ettiğini göstermektedir. Bunlarla birlikte Reji Şirketi'nin Duyun-u Umumiye’ye bağlı bir şirket olduğu ve Duyunu Umumiye'nin de Osmanlı dış borçlarını tahsis etmek üzere kurulduğu gerçeği göz önüne alınınca, şirketin amacının tütün sektörünü geliştirmekten çok, tütün sektöründen nasıl daha fazla gelir elde edilebileceği sonucu çıkmaktadır.

Şirketin İstanbul'daki fabrikası olan, Cibali Tütün Fabrikası; Reji Şirketi'nin en çok mamül mal çıktısının alındığı fabrikadır. Bu fabrika da işçilerin çalışma koşulları, dönemin İstanbul işçisinin ortalama koşullarının altındadır. Bundan ötürü, Reji Şirketi’nin faaliyet gösterdiği yıllarda, reji işçisinin, hareketlenmelerine yoğun bir şekilde rastlamak mümkündür. Bu hareketlenmelerin en çok görülen grevlerdir. Reji işçisinin grevi, sadece grev karakteri barındırmaz; bazen basın açıklaması görülürken bazen de makine kırıcılığını(luddisme) da kapsamaktadır. Bu makalede, bu grevlerin sebeplerinin ve taleplerinin birbirlerinden ayrı şeyler olduklarını ve yapılan grevler sürecinde reji işçisinde oluşan "işçi sınıfı bilinci”" açıklanmaktadır.

Cibali reji işçisinin 1883-1925 yılları arasında yedi adet grevine rastlanmıştır. Bu grevler katılımcı sayısı ve katılımcı özellikleri bakımından değişkenlik göstermiştir. Bu grevlerden biri ile alakalı arşiv belgesine rastlanmazken, öteki altı grevle alakalı birincil(arşiv belgesi) ve ikincil(mecmua,gazete vs.) kaynaklara ulaşılarak, grev sebeplerinin sosyo-ekonomik sebeplerinin farklılık gösterdiği; ancak grev taleplerinin dönemlere göre güncellenerek sabit tutulduğu görülmüştür. Grev sebeplerine bakıldığı vakit; otomasyon, dini-kültürel sebepler, özgürlük talebi ve angarya görülmektedir. Bu sebeplerin sonucunda işçi, grev yapmakta ve ekonomik taleplerde bulunmaktadır, bu talepler genel olarak yevmiyelere zam yapılması, mesai sürelerinin kısaltılması ve fabrika sağlık koşullarının iyileştirilmesi üzerinedir.

Cibali reji işçisi, grevler süresince "işçi sınıfi bilinci”ni oluşturabilmiştir. Tespit edilen ilk ve son grev arasındaki farklılıkları incelendiği vakit, ilkinde greve katılım 52 işçi ile başlarken, son grevde katılımın neredeyse 1400 işçi civarında olduğu belirtilmiştir. Bu süreçte, Cibali reji işçilerinin, Selanikli reji işçilerinden etkilendiği belirtilmiş ve sosyalist düşüncelerle tanıştığı açıklanmıştır. Çünkü Osmanlı işçi hareketlerine bakıldığı vakit, ilk defa sosyalist işçilerin Selanik'te olduğu görülmüştür. Ancak İstanbul'da karışıklık çıkarabilecek herhangi bir ideolojinin yayılımına izin verilmediği için Cibali reji işçileri arasında sosyalizm yayılmamıştır. Oluşan bu işçi sınıfı bilincine gayrimüslimlerin daha çok itibâr ettikleri görülmektedir; nitekim 1911-Nisan Grevi’ne bakıldığı vakit artık, işçilerin birbirleri üzerinde greve katılım konusunda baskı yaptıkları görülmektedir. Bu bilinç ilerleyen süreçte kendini iyice hissettirmiş ve bundan sonra oluşan grevlerde neredeyse tam mevcut ile katılım olmuştur.

Reji Şirketi’nin uyguladığı baskılardan ötürü oluşan grevleri “organize eylem”diye nitelendiremeyiz. Çünkü grevlerin oluşumu tepkisel karakterlidir. Ayrıca bu grevleri organize edecek olan sendikal oluşumlar 1908 yılına kadar gelen hukuki kısıtlamalar neticesinde kurulamamıştır.

Reji Şirketi 1925 yılında devlet tarafından satın alınarak millileştirilmiştir. Ancak yeni kurulan Türkiye Cumhuriyeti, Osmanlı Devleti'nin kurum ve mevzuatını tekel bağlamında devam ettirmiştir. Bundan ötürü Cumhuriyet döneminde de tekel işçilerinin grevlerinin devam ettiği bilinmektedir.

\section{KAYNAKCA}

Balsoy, G.(2009).“Gendering Ottoman Labor History: The Cibali Régie Factory in the Early Twentieth Century”, International Review of Social History, 45-68.

BOA A. DVN.MKL. 55/22 8 Şevval 1331/10 Eylül 1913.

BOA BEO 2794/209533 5 Safer 1324/31 Mart 1906.

BOA BEO 2799/209903 13 Safer 1324/8 Nisan 1906.

BOA DH. EUM. KADL 14/22 17 Rebiülahir 1329/17 Nisan1911.

BOA DH. İD 107/24 14 Cemaziyelahir 1329/13 Mayıs 1911.

BOA Y.A.HUS 501/44 6 Safer 1324/1 Nisan 1906.

BOA Y.A.HUS. 481/105 22 Rebiülahir 1322/30 Kasım 1904. 
Süleyman Demirel Üniversitesi Vizyoner Dergisi, Yıl: 2018, Cilt: 9, Sayı: 20, ss.28-38.

Suleyman Demirel University Visionary Journal, Year: 2018, Volume: 9, Number: 20, pp.28-38.

BOA ZB 383/82 30 Temmuz 1324/12 Ağustos 1908

BOA ZB 74/31 4 Ağustos 1324/17 Ağustos 1908.

BOA, Y.A. HUS. 273/60 10 Şubat 1310/27 Nisan 1893.

Cemal Paşa(2012).Hatırat (1913-1922), Ahmet Zeki İzgöer(haz.), İstanbul, Nehir Yayınları.

Dığıroğlu, F.(2007). Memalik-i Osmaniye Duhanları Müşterekü'l-Menfaa Reji Şirketi- Trabzon Reji İdaresi (1883-1914), İstanbul: OBA Yayınları.

Düstûr, 2. Tertip, C.1. 03.Ağ.1325/ 16.08.1909, Dersaadet Matbaas1, 1329.

Düstûr, 2. Tertip, C.1. 27.T.1325/ 09.08.1909, Dersaadet Matbaas1, 1329.

Erkson, H. N.(1954). Türkiye Tütünleri-Tütünün Türkiye'deki Tarihi, İstanbul: Yeni Matbaa

Karakışla, Y.S.( 1998). “Osmanlı Sanayi İşçisi Sınıfının Doğuşu” Osmanlı’dan Cumhuriyet Türkiye'sine İşçiler 1839-1950 içinde, D. Quataert, E.J. Zürcher (Der.),İstanbul: İletişim Yayınları.

Kazgan, H.(1999).Osmanlı'dan Cumhuriyet'e Şirketleşme, İstanbul: Vakıfbank Yayınları.

Mutluçağ, H.(1967). “Duyûn-1 Umumiye ve Reji Soygunu”, Belgelerle Türk Tarihi Dergisi, 2, 33-39.

Oktar, T.(1992).Osmanlı Devleti'nde Reji Şirketi (Memaliki Şahane Duhanları Müşterekül Menfaa Reji İdaresi), İstanbul: Bilim-Teknik Yayınevi.

Ökçün, G.(1970).1913-1915 Yılları Osmanlı Sanayi İstatistikleri, Ankara, Ankara Üniversitesi SBF Yayınları No:299.

Pamuk, Ş.( 2007).Osmanlı Ekonomisi ve Kurumları, İstanbul: Türkiye İş Bankası Kültür Yayınları.

Quataert, D. (1987).Osmanlı Devleti’nde Avrupa İktisadi Yayılımı ve Direniş (1881-1908), S. Tekay (Çev.), Ankara: Yurt Yayınları.

Quataert, D. ve Zürcher, E. J. (1998).Osmanlı'dan Cumhuriyet Türkiyesi’ne İşçiler 1839-1950, İstanbul, İletişim Yayınlar1.

Reji Amelesi(31.T .1324/13.08.1908), Tanin, Sayı:13.

Reji Amelesinin Metalibat1(01.Hzr.1336/01.06.1920) İkdam Gazetesi.

Reji Amelesinin Ta’til-i Eşgali(23.Ma.1327/05.04.1911), Sa’y ve Amel, Sayı:8.

Reji Fabrikasında(31.T.1324/13.08.1908), Servet-i Fünun, Sayı:19.

Reji ve Amelesi(09.Hzr.1336/09.06.1920), İkdam Gazetesi.

Ricardo, D.( 2008).Vergilendirmenin ve Siyasal İktisadın Prensipleri, B. Zeren (Çev.), İstanbul: İş Bankası Kültür Yayınları.

Sülker, K.(1976).Türkiye'de İşçi Hareketleri, İstanbul:Gerçek Yayınevi.

Şanda, H. ( ), 1908 İşçi Hareketleri-Yarı Müstemleke Oluş Tarihi, Gözlem Yayınları.

Tabakoğlu, A.( 2009). Türkiye İktisat Tarihi, İstanbul: Dergâh Yayınları.

Toprak, Z.(1977). “1908 İşçi Hareketleri ve Jön Türkler” Yurt ve Dünya, 2, 227-295.

Tütün İşçileri(1340(1924)). Aydınlık Mecmuası, Sayı:6.

Velay, A. D. (1946).Türkiye Maliye Tarihi, Ankara, Maliye Tetkik Kurulu Yayınları, C. Serisi, No:4.

Velikov, S.(1964). "Sur Le Mouvement Ouvrier Et Socialiste En Turquie Après La Rèvolution Jeune-Turque De 1908”, Etudes Balkaniques, 1, 29-47.

Yıldırım, K.( 2011). Osmanlı Çalışma Hayatında İşçi Örgütlenmesi ve İşçi Hareketlerinin Gelişimi (1870-1922), Doktora Tezi, İstanbul Üniversitesi. 